\title{
Economic Strain, Ethnic Concentration and Attitudes Towards Foreigners in the European Union*
}

by

\author{
Ira N. Gang \\ Department of Economics, Rutgers University \\ gang@economics.rutgers.edu \\ http://fas-econ.rutgers.edu/home/gang/ \\ Francisco L. Rivera-Batiz \\ Department of Economics, Columbia University \\ flr9@columbia.edu \\ http://columbia.edu/ flr9/ \\ Myeong-Su Yun \\ Department of Economics, University of Western Ontario \\ myun@uwo.ca \\ http://publish.uwo.ca/ myun/
}

November 14, 2001

\begin{abstract}
This paper provides a statistical analysis of the determinants of attitudes towards foreigners displayed by Europeans sampled in Eurobarometer surveys in 1988 and 1997. Europeans who compete with immigrants in the labor market have more negative attitudes towards foreigners. In addition, an increased concentration of immigrants in local neighborhoods increases the likelihood of negative attitudes. Racial prejudice exerts a strong influence on anti-foreigner sentiment. The generally rising trend towards greater racial prejudice, and the decline in the strength of educational attainment in reducing negative attitudes towards foreigners, contribute to the increasing anti-foreigner attitudes between 1988 and 1997.
\end{abstract}

Keywords: anti-foreigner, labor force status, ethnic concentration, probit decomposition, racial prejudice, attitudes, sentiments towards migrants

JEL Classifications: J15, J61, F22

* This manuscript benefitted from comments on an earlier version by Christian Dustmann, Christoph M. Schmidt, and by seminars at Lafayette College and the European Society for Population Economics. Ira Gang thanks the Humboldt Fellowship and Rutgers Research Council for their partial support. Myeong-Su Yun's work was supported by the CIBC Program in Human Capital and Productivity, Department of Economics, University of Western Ontario.

Correspondence: Ira Gang, Economics Department, Rutgers University, 75 Hamilton St, New Brunswick NJ 08901-1248 USA.

CIra N. Gang, Myeong-Su Yun and Myeong-Su Yun. All Rights Reserved. 


\section{Introduction}

The population of foreigners in the countries of the European Union has risen sharply in recent years. The 1990's has seen the share of the population change in the European Union accounted for by net immigration exceed that of natural population growth for the first time in many decades [OECD (2001, p. 33)]. For some countries, migration has played a dominant role in population growth. In Germany, for instance, the natural increase of the population since the 1970s has been negative and net immigration totally accounts for population growth. The same phenomenon has emerged in Greece, Italy and Sweden, where natural population growth turned negative in the late 1990 s and their populations rose only as a result of net immigration.

This demographic phenomenon has led to a substantial increase in the portion of the population accounted for by foreign nationals in some European countries. Table 1 shows that, in 1998, foreigners constituted 36 percent of the population in Luxembourg, 9.1 percent in Austria, 8.7 percent in Belgium, and 8.9 percent in Germany. For some countries, these figures underestimate the significance of immigration, as they include only foreign-born individuals who are not citizens or have not been naturalized. In Sweden, for example, foreign nationals constituted 4.2 percent of the population in 1998 but the total foreign-born population, including both foreign nationals as well as naturalized foreign immigrants and Swedish citizens born abroad, was 10.8 percent of the population. By comparison, the proportion of the foreign-born in the population of the United States, a country famed for its open immigration policy, was 9.8 percent in $1998 .^{1}$

The immigration flows in the European Union have been magnified by the rise of refugees

${ }^{1}$ Note that international migration data have not been standardized and hence, when one refers to the fraction of "foreigners" in the population or to the "foreign-born," one may be talking about different demographic groups in different countries; see OECD (2001, pp. 295-301). 
and asylum-seekers in the late 1980s and throughout the 1990s. Although laws to curb refugees and asylum-seekers have been passed in some countries, the ripples of the massive immigration flows associated with civil war and socioeconomic strife in Africa, Eastern Europe and Central Asia remain today. In 1983, approximately 30,000 people asked for asylum in the European Community countries. This number rose quickly in the late 1980s and early 1990s and it peaked at 680,000 in 1992. Since then, the number of asylum seekers has declined but still remains at high levels compared to the situation in earlier decades. In 1999, a total of 390,000 asylum-seekers entered the European Community countries. In Germany, the European country receiving the largest number of refugees, the number of asylum-seekers rose from 121,000 in 1989 to a peak of 438,000 in 1992, gradually declining to 95,100 in 1999 .

The rise of immigration in the 1990s was associated with increased anti-foreigner attitudes in some countries. In Great Britain, for example, the number of racially motivated incidents reported to the police grew from 4,383 in 1988 to 7,793 in 1992 and 13,878 in $1998 .^{2}$ This trend exploded in the summer of 2001 when South Asian immigrants in Britain rioted in the cities of Bradford, Oldham, Leeds and Burnley, in large part to protest growing violence and anti-immigrant attitudes and violence. In Germany, the number of criminal offences with racist/xenophobic motives was 10,037 in 1999, of which there were 746 racially-motivated acts of violence reported to the police. A number of these attacks resulted in death, as in the case of an Algerian man who died on February 13, 1999 as a result of injuries he suffered as he was fleeing from his attackers, and a man from Mozambique who died in Bavaria as a result of injuries received in an attack on August 15, 1999.

\footnotetext{
${ }^{2}$ The number of incidents reported to the police grossly underestimates the actual number of such incidents since most remain unreported. In 1996, the British Crime Survey estimated that 143,000 offences against ethnic minorities (transgressions considered by the victim to be racially-motivated) had been committed the year before [Channel4 (2000)].
} 
In France, the killing of a 17-year-old African immigrant in Marseilles in February 1995 led to a wide debate over the foreign-born population in the country, a controversy that spilled-over into the French presidential campaign at the time. Anti-foreigner violence has also been on the rise in other European Union countries [see EUMC (2000)].

Attitudes towards foreigners often depend on where the foreigners come from. Dustmann and Preston (2000) show that in the United Kingdom, attitudes towards foreigners from other European countries are more favorable than those towards Asians or West Indians. Table 2 shows the decomposition of the population of foreigners in some European Union countries in 1998 on the basis of country of origin. The proportion of non-EEC countries in the contingent of foreigners vary from 37 percent in Belgium to 86 percent in Italy. In the U.K., 60 percent of the foreign-born population comes from non-EU countries and 14 percent from Asian countries.

What explains the rise in negative sentiments towards non-European immigrants among some segments of the European population in recent years? Is economic strain in the host countries, in the form of stagnant earnings or rising unemployment, the key to understanding anti-immigrant activities or are non-economic factors, such as prejudice and racism, more influential in determining such behavior? This paper explores the determinants of the attitudes of European citizens towards non-European Union foreigners using samples from the 1988 and 1997 Eurobarometer Surveys. The Eurobarometer survey is carried out every year and samples European attitudes towards a wide array of subjects. Both in 1988 and in 1997, the surveys included specific questions measuring attitudes towards immigrants and immigration. We utilize the answers to these questions to carry out an analysis of some of the key factors influencing the attitudes of European Union citizens towards foreigners and their changes over time.

In the next section we discuss the various forces that have been presented in the literature as 
possible factors generating anti-immigrant sentiments in host nations. Section III offers some background on the Eurobarometer survey data sets utilized in this paper, and presents mean characteristics of the sampled populations. Section IV examines the determinants of attitudes towards foreigners by utilizing a probit analysis of the relative influence of various economic and non-economic variables on such attitudes. Section V employs a probit decomposition analysis to examine and explain the changes in attitudes between 1988 and 1997. Finally, Section VI provides a summary of our results.

\section{The Determinants of Anti-Immigrant Attitudes}

Over the years, conjectures on the determinants of anti-immigrant sentiments have been based more on heavy theorizing and casual evidence [see, for instance, Alber (1994)]. Recently, however, a number of empirical studies have emerged utilizing comprehensive survey data.

The most popular explanation for the emergence of negative sentiments towards immigrants is ethnic or racial prejudice, whose strength is often related to the presence and concentration of immigrants within particular communities. In the United States, historically, there is substantial evidence that racial prejudice was a major factor behind restrictionist movements that reduced immigration flows from particular countries or regions, such as China and Mexico [see, for example, Gutierrez (1995)]. ${ }^{3}$ Racial prejudice has also been found in many of the anti-immigrant activities

\footnotetext{
${ }^{3}$ The extensive literature on racial segregation in the United States also serves as a background for this perspective. This literature suggests that the rise of racial segregation and housing discrimination in certain cities of the United States was linked to the increased visibility and growth in the concentration of black Americans in those cities. As Massey and Denton (1993, p. 10) point out: "...the black ghetto was constructed through a series of well-defined institutional practices, private behaviors, and public policies by which whites sought to contain growing urban black populations." Growing immigrant communities may have faced similar behavior.
} 
documented in the last few years in European countries. This was evident in the 2001 British immigrant riots. In the city of Oldham, England, where immigrant unrest occurred in May 2001, immigrants complained of racial prejudice as a source of their frustration. As the New York Times [Lyall (2001, p. A4)] reported: "[There is] a sense among nonwhites that Britain, and Oldham, are racist places. Leaving aside obviously provocative language, many nonwhites say that low-grade racism is an underlying fact of life here." In fact, the growing visibility of the immigrants appears to have intensified anti-immigrant sentiments. In Bradford, England, where immigrant riots erupted in July 2001, the city of half a million residents includes a visible population of about 100,000 Asian immigrants. This population is itself highly segregated within Bradford, further contributing to tensions between the immigrants and the rest of the population.

A second force which is frequently postulated as an explanation for anti-immigrant attitudes is economic in nature. It is hypothesized that in countries where economic strain is present, with stagnant or collapsing income and/or employment opportunities, immigrants will be partly blamed for the economic stress thus generating the resentment of the native-born population. Whether immigration does in fact act to lower wages or reduce unemployment opportunities is a matter of debate. For instance, evidence on the impact of immigrants on European labor markets is inconclusive, often finding small effects of immigration on unemployment. ${ }^{4}$ Studies on the United States also find small wage and unemployment effects of immigration. ${ }^{5}$ Indeed, economic theory warns us against hastily assuming that a flow of immigrants into an economy will raise the

\footnotetext{
${ }^{4}$ See the survey paper by Zimmermann (1995), as well as Hunt (1992), DeNew and Zimmermann (1994), Muhleisen and Zimmermann (1994), Winter-Ebmer and Zweimueller (1994), and Winkelmann and Zimmermann (1993).

${ }^{5}$ See Card (1990) for empirical evidence on this issue relating to the Mariel immigrant flow. See also Card (2001) for further evidence.
} 
unemployment of natives or reduce their wages. If native-born are complements to immigrants, the foreign labor inflow increases the demand for natives, thus raising --rather than lowering-- their employment. $^{6}$

On the other hand, this debate on the economic effects of immigration may not be directly relevant to the formation of attitudes of natives towards the immigrants, which are based on perceptions about how immigrants affect the economy, perceptions that are not necessarily based on reality. ${ }^{7}$ For example, even if the measured employment or wage effects of immigrants are very small, people may be influenced by rumors and stories reported in the media or heard in the streets about the "immigrant invasion" which is taking jobs away from them. Those who are directly competing with immigrants for jobs and who may be seeking a factor to blame for job losses, may be more responsive to these rumors and biased stories, developing strong negative attitudes towards foreigners - particularly if the press and politicians make the topic a big issue.

The relative roles of the various factors influencing attitudes towards foreigners have been examined in a set of recent papers on the issue. Krueger and Pischke (1997) provide a statistical analysis of the various forces influencing crimes against foreigners in Germany. They find significant variation in the incidence and pattern of violence against foreigners on the basis of location. However, they also conclude that "economic strain," as measured by high unemployment or low wages, seem to contribute little to the incidence of violence once location is taken into account.

While Krueger and Pischke (1997) study the causes of crime against foreigners in Germany,

${ }^{6}$ For a discussion of the issue of complementarity between immigrant and native-born workers, see Gang and Rivera-Batiz (1994a).

${ }^{7}$ The question of perception versus reality in viewing migrants is taken up by Fertig and Schmidt (2001). 
Gang and Rivera-Batiz (1994b), Dustmann and Preston (2000, 2001) and Bauer, Lofstrom and Zimmermann (2000) all study attitudes towards foreigners. One finding is that high concentrations of ethnic minorities are associated with more hostile attitudes towards immigrants in Germany [Gang and Rivera-Batiz (1994b)] and in the United Kingdom [Dustmann and Preston (2001)]. On the other hand, Dustmann and Preston (2000) find evidence that both welfare and labor market concerns also matter for the formation of attitudes towards future immigrants, but that the most important factor is non-economic: racial bias. Bauer, Lofstrom and Zimmermann (2000) study the effect of different immigration policies in OECD countries on attitudes towards immigrants.

In this paper we study the determinants of attitudes towards foreigners among European Union citizens, and the changes in these attitudes between 1988 to 1997 . The relative role played by economic strain, racial prejudice and ethnic concentration in determining negative attitudes towards immigrants is examined.

\section{The Eurobarometer Survey and the Empirical Model}

The analysis in this paper uses the 1988 and 1997 Eurobarometer Surveys. The Eurobarometer surveys are carried out every year in European countries in order to examine attitudes towards a variety of issues. The surveys give rise to unique data sets consisting of cross-sections of a geographically distributed random sample of households across Europe [see Reif and Melich (1992) and Melich (1999) for detailed descriptions of the procedures followed in each country]. In addition to information on household economic and demographic behavior, the 1988 and 1997 Eurobarometer surveys contained detailed questions on attitudes towards immigrants and foreigners. We first measure attitudes towards foreigners on the basis of the responses of residents of European Union countries, as sampled by the 1988 Eurobarometer survey, to the question: "Is the presence of 
(non-European Community) foreigners good or bad for the future of our country?" We construct the variable ANTI-FOREIGNERS, equal to one if the respondent declares that foreigners are "bad" or "a little bad" for the future of their country, and zero otherwise. This qualitative variable will be used later as the dependent variable in a probit analysis establishing the impact of various explanatory variables on the probability of a person displaying negative attitudes towards foreigners.

The variable ANTI-FOREIGNERS captures in a very straightforward and obvious manner a dislike of foreigners. Unfortunately, the question was not asked of survey respondents in the 1997 Eurobarometer survey, and hence its use does not allow us to make inter-temporal comparisons. We construct another dependent variable for use in our analysis, based on responses to another question which appears in both the 1988 and 1997 Eurobarometer surveys. This question asked respondents whether there were "too many," "a lot, but not too many," or "not many" foreigners living in their country. The binary variable TOO-MANY-FOREIGNERS is equal to one if the respondent answered that there were too many foreigners in their country and zero otherwise. We utilize TOOMANY-FOREIGNERS as our main dependent variable. In addition, at several places in the paper we will make comparisons of our results for 1988 using the ANTI-FOREIGNERS and TOOMANY-FOREIGNERS variables. We will show that these two variables display similar behavioral patterns.

Table 3 presents the attitudes of European residents towards foreigners, on the basis of the two variables, ANTI-FOREIGNERS and TOO-MANY-FOREIGNERS. The first row shows the results for the overall Eurobarometer samples in 1988 and 1997. As can be seen, in 1988, 31.4 percent of all respondents answered that foreigners were "bad" or "a little bad" for the future of their country. In addition, in that same year, 29.5 percent indicated that there were "too many foreigners" in their country. By 1997, the percentage of people answering that there were too many foreigners 
in their country had risen to 42.1 percent. This substantial increase in anti-foreigner attitudes is consistent with the observations noted in the introduction, indicating greater anti-foreigner activity in some European countries.

What explains negative attitudes towards foreigners and why has there been such a marked increase in anti-foreigner sentiment among native European residents? The previous section points out that one answer may lie in the economic strain encountered by people. In a large part of Europe, a slowdown in growth and rising unemployment characterized the 1980s and 1990s. In Germany, for instance, unemployment rose from 2.9 percent in 1979 to 6.3 percent in 1988 and 9.9 percent in 1997. In France, the unemployment rate jumped from 6.1 percent in 1979 to 10.3 percent in 1988 and 12.4 percent in 1997. And in Italy, unemployment rose from 4.9 percent in 1979 to 7.9 percent in 1988 and 12.3 percent in 1997. The rising unemployment could lead to anti-foreigner attitudes as those who are fired and laid-off seek a target to blame their ills on. Has that been the case in Europe?

On the top half of Table 3 we decompose the 1988 and 1997 Eurobarometer samples into various labor force categories which show that anti-foreigner attitudes vary by labor force group and by year. For instance, in 1988, almost one third, or 31.37 percent, of the people who were unemployed declared that foreigners were "bad" or "a little bad" for their economy, but only 26.15 percent of students declared the same. In 1997, 42.30 percent of the people who were unemployed declared that there were "too many" foreigners, but only 26.71 percent of students declared the same that year. The retired have the highest rates of anti-foreigner behavior in the sample. In 1988, 38.05 percent of the retired declared that there were too many foreigners in their country; in $1997,52.25$ percent of the retired declared the same. Note that negative attitudes towards foreigners rise between 1988 and 1997 for every group in the sample, especially for the non-retirees out of the labor force. Often unemployment is used in economic studies to capture economic strain. But Table 3 
shows that the unemployed do not demonstrate a markedly more negative view towards foreigners than the employed or retirees. The fact is that it is not just the unemployed but various groups in the economy that face, or perceive that they face, economic strain brought on by foreigners, as discussed in Section II. The employed may be threatened by the possibility of lower wages resulting from immigration; retirees may be encouraged to retire by the presence of younger immigrants ready to take their place. Below, in Section IV, we will formally test which groups are enduring the most (perceived) strain.

Another major explanation for anti-foreigner attitudes is the greater racial or ethnic bias that may be generated by the visible presence of immigrants in certain communities. The rise in European immigration was previously noted in the introduction. Is this factor behind the rise in anti-foreigner attitudes? To test this hypothesis, we use two different questions as explanatory variables. First, in 1988 , the survey asked respondents to characterize the relative size of the foreign-born population in their neighborhood, with answers including: "many foreigners," "few foreigners," and "no foreigners." On this basis, we construct two dummy variables, MANY and FEW, equal to one if a person answered that there were "many," or "few" foreigners in their neighborhood, respectively, and zero otherwise. We utilize the MANY/FEW variables in our probit analysis below to examine the role played by larger concentrations or greater visibility of foreigners on European attitudes towards them. If we find that greater visibility breeds anti-foreigner attitudes, we presume that an element of racial/ethnic prejudice is involved in those sentiments.

The simple correlation between increased concentrations of immigrants and negative attitudes towards foreigners is clearly shown among those sampled by the Eurobarometer survey. Of those who thought that their neighborhood had "many" foreigners, 42 percent answered that foreigners "were not good for the future of the country" and 46 percent thought that there were "too 
many" foreigners in their country. This is substantially higher that the comparable figures for those who thought that their neighborhood had "few" foreigners: for this group, 31 percent thought foreigners "were not good for the future of the country," and 28 percent thought that there were "too many" foreigners in their country. For those who responded that their neighborhood had no foreigners, the corresponding percentages are 29 percent and 28 , respectively. Of course, our analysis below will examine whether this simple correlation holds in a multivariate analysis of anti-foreigner attitudes.

A second and different question concerning racial bias was asked both in the 1988 and 1997 Eurobarometer surveys as to whether respondents felt that the presence of people from another race was disturbing or not. We construct a dummy variable DISTURBING equal to one if the person answered yes to this question and zero otherwise. Table 3 shows that 65 percent of those disturbed by the existence of other races also held anti-foreigner attitudes in 1988 (that the presence of foreigners was bad for the future of the country), and 63 percent thought that there were too many foreigners in their country. With respect to the latter, by 1997 the percentage of people who felt that there were too many foreigners in their country climbs to 80 percent among those disturbed by the existence of other races. On the other hand, Table 3 also shows that people who were not disturbed by the presence of other races also displayed sharply lower anti-foreigner attitudes, although even among these groups anti-foreigner attitudes also rose between 1988 and 1997.

Although interesting, the simple correlations obtained from Table 3 can only be suggestive. The reason is that the observed connections may be caused by other variables not examined in that Table. For instance, the stronger negative sentiments of the retired against foreigners, as compared to students, may be age-related. Older generations may have stronger anti-immigrant feelings. Or, the observations can be due to differences in the educational attainment between the older and 
younger generations. In order to keep other things constant, one must therefore carry out a multivariate analysis of the factors determining anti-immigrant attitudes.

We carry out a probit analysis of the two attitude variables defined earlier: ANTIFOREIGNERS and TOO-MANY-FOREIGNERS. In the probit analysis, the probability of observing negative attitude towards foreigners is defined as Prob(TOO-MANY-FOREIGNERS = $1)=\Phi(X \beta)$, where $\Phi$ is a standard normal cumulative distribution function, $\beta$ is a set of estimated coefficients and $X$ includes various explanatory variables to be specified below. We carry out a similar analysis using ANTI-FOREIGNER as the dependent variable in the probit equation.

In addition to the explanatory variables capturing labor force status, racial bias, and the relative visibility of foreigners in the neighborhood, we include in our analysis a number of background and demographic variables. First, we include the generational impact reflected by the age of the person. We use two variables: AGE (number of years), and AGESQUARE (number of years of age squared divided by 100), to reflect decreasing or increasing effects of age on attitudes. In addition, we define the variable EDUCATION (years of schooling), which we expect to be inversely associated with negative attitudes towards immigrants, partly because most educational systems willfully act to reduce prejudice and bias, and partly because more educated European residents are less likely to be negatively affected by the less-skilled foreigners; in fact, they may have benefitted from low-wage foreigners. We also examine differences in attitudes based on gender, including a dummy variable MALE, which is equal to one if the person was male and zero otherwise.

The dummy variable HEAD-of-HOUSEHOLD is equal to one if the person is the head of household and zero otherwise. We expect HEAD-of-HOUSEHOLD to be associated with more negative attitudes towards foreigners because any perceived negative economic effects of the immigrants will be magnified for heads of household, who are in charge of the economic affairs of 
their families. We also include the variable CHILDREN15, which equals the number of children less than 15 years of age living in the household where the respondent resides. Since households with a greater number of children may be subject to deeper economic strains, one could possibly anticipate CHILDREN15 to be associated with anti-immigrant attitudes.

As users of public services, immigrants profit greatly from public education. Being comparatively young, and with family sizes that exceed the average, immigrant families tend to have on average more children in public schools than the average. The impact of this on the budget of the public sector has not gone unnoticed. Both in Europe and in the United States, a controversy has raged in recent years about the impact of immigrants on social spending, including public education spending. ${ }^{8}$

The next section presents our analysis of the specification we have discussed.

\section{Results}

This study focuses on the attitudes of the citizens of European Union countries aged $16-70$ years, not of foreign origin and not in the military. Respondents who did not answer questions as to their nationality, occupation, age or sex were removed from the sample. The remaining sample of citizens of the European Union was equal to 9,775 in 1988 and 11,868 in 1997.9

\footnotetext{
${ }^{8}$ This concern has been especially sharp in relation to the children of illegal immigrants. Indeed, legislation has been debated about whether the children of illegal immigrants can, or should, be excluded from access to public education. Given the publicity accorded to these issues, parents of young children, concerned with the impact of foreigners on social spending, may have more negative attitudes towards foreigners.

${ }^{9}$ We restrict the sample to respondents in countries that were members of the European Union in 1988: Belgium, Denmark, France, Germany, Greece, Ireland, Italy, Luxembourg, the Netherlands, Portugal, Spain and the United Kingdom.
} 
Table 4 shows the mean characteristics of the samples. The average age is approximately 40 to 41 years for both 1988 and 1997. The educational attainment of the sample rises from 11.2 to 11.8 years. About half of the two samples (49 percent) consist of men; close to one-half are household heads; and the average number of children less than 15 years of age per household is 0.65 in 1988 and 0.59 in 1997. In 1988, 39 percent of the sample were employed in wage/salary jobs, 6 percent were unemployed, 12 percent were retired, 11 were percent self-employed, 11 percent were students, and 20 percent were non-retirees out of the labor force. By 1997, employment increased to 43 percent, unemployment to 8 percent, retirees to 15 percent, while the self-employed, students and non-retirees out of the labor force fell to 10 percent, 10 percent and 13 percent, respectively.

The visibility of foreigners in a neighborhood is measured by the dummy variables MANY and FEW. As noted earlier, these variables are based on responses to the 1988 Eurobarometer survey question as to whether there were "many," "few," or "no" foreigners residing in the neighborhood of the respondents. Almost half of the sample (48 percent) declared that there were no foreigners residing in their neighborhood, while 43 percent stated there were a few foreigners in their neighborhood, and 8 percent said that there were many foreigners.

Finally, the variable DISTURBING measures the percentage of the sample stating that they found the presence of people of another race disturbing. The proportion of the sample saying yes to this question was 12 percent in 1988 and 16 percent in 1997.

Table 4 also shows the mean values of the dependent variables in the probit analysis. In terms of the equation for the dependent variable ANTI-FOREIGNERS, which is available only for 1988, about 31 percent of the sample had a value equal to one, that is, 31 percent declared that the presence of immigrants is "bad" or a "little bad" for the future of their country. For the dependent variable TOO-MANY-FOREIGNERS, which is available both in the 1988 and 1997 samples, 30 percent of 
the sample in 1988 and 42 percent of the 1997 sample had a value of one, that is, answered that there were too many foreigners in their country.

The estimated probit coefficients are reported in Tables 5 thru 7. In Tables 5 and 6 we present the results using TOO-MANY-FOREIGNERS as the dependent variable. Table 7 repeats the analysis presented in Table 6, this time with ANTI-FOREIGNERS as the dependent variable.

The main sets of probit results are displayed in Table 5. First, the estimated coefficients show that greater educational attainment is associated with a statistically significant reduction in the probability of displaying negative attitudes towards foreigners, with everything else held constant. The negative coefficient on CHILDREN15 suggests that people residing in households that have a larger number of children under the age of 15 have more positive attitudes towards foreigners. This is contrary to the expectations we had on the sign of this coefficient. This may be explained by the increased likelihood that the children of natives will mix with the children of immigrants, increasing their contact and diffusing the tensions between the adults in the two groups.

The probit results in Table 5 show the partial correlation between attitudes towards foreigners and various, disaggregated labor market groups, including the employed, unemployed, retired, selfemployed, and non-retirees out of the labor force (note that students are the reference group). The statistical significance of the coefficients on the dummy variables varies substantially across these groups and across years. The main focus of the existing literature is "Do the unemployed have stronger negative attitudes towards foreigners than other groups?” A null hypothesis, $\beta$ (unemployed) $=\beta($ employed), was tested using a likelihood ratio test [see Amemiya (1985), section 4.5] in order to determine whether or not unemployment increases the likelihood of forming more negative attitudes towards foreigners relative to the employed. This null hypothesis cannot be rejected at the 5 percent level in 1988 or 1997 . This means that the likelihood of having negative attitudes towards 
foreigners is not different between the employed and unemployed in either year.

Does this result imply that economic strain is unrelated to negative attitudes towards foreigners? It may imply that economic stress in the form of unemployment may not be the only cause of negative attitudes towards foreigners. Both the employed and unemployed may perceive economic strain caused by immigrants, albeit in different ways. The important commonality is that their well-being is affected by changing wages and by employment rates, both of which popular lore feels are negatively affected by immigrants. Another finding common to both years is that being retired is also associated with negative attitudes towards foreigners. The retired were workers in the past, subject to the vagaries of wages and employment rates, and attitudes towards foreigners formed in earlier years do not necessarily disappear over time, after retirement.

One hypothesis is that the people in these three categories (the employed, the unemployed and the retired) may have similar attitudes towards foreigners, as compared to people in other categories, holding other things constant. One might expect that individuals, who are in these three categories, would perceive (currently or in the past) that their earnings and employment opportunities could be negatively affected by immigrants, and thus would have stronger anti-immigrant attitudes. In order to test this hypothesis, we substituted the various labor force status categories shown in Table 5 with the variable LABOR MARKET COMPETITORS, which is equal to one if the person is employed, unemployed or retired, and zero otherwise. Table 6 presents our probit analysis for negative attitudes towards foreigners, using the variable LABOR MARKET COMPETITORS as an explanatory variable instead of the disaggregated categories that appear in Table 5. Note that labor market competitors made up 57 percent of the sample in 1988 and 66 percent in 1997. For both 1988 and 1997, we find that being a labor market competitor (currently or in the past) has a statistically significant positive impact (at least at a 5 percent significance level) on the likelihood 
that a person has negative attitudes towards foreigners, holding other things constant. This suggests that economic strain magnifies negative attitudes towards foreigners.

Some comments are warranted here. First, it is well documented that immigrants often choose to be self-employed [e.g., Yuengert (1995)]. Also, since the self-employed are labor market participants, it could be argued they should be considered in the cateogory LABOR MARKET COMPETITORS. Being self-employed in 1988, however, does not significantly increase one's negative attitudes towards foreigners. It is possible that the self-employed did not face intensive competition with immigrants in 1988 . Second, it is interesting to note the changes in the significance of the coefficients of the different labor force categories between 1988 and 1997. Indeed, every category significantly demonstrated increased negative attitudes towards foreigners relative to the students in 1997. By 1997, it appears that only the students are different from other labor force categories. This maybe because students perceive the least economic strain caused by the increasing immigration since their interests are the most remotely related to the labor market. ${ }^{10}$

We now turn our attention to racial/ethnic bias and its role in fomenting anti-foreigners attitude. The results on this issue reported in Tables 5 and 6 are consistent and robust. These tables include two measures that are linked to racial/ethnic prejudice. First, the results for 1988 presented in column 1 of Table 5 show that a greater concentration of foreigners in a particular location increases negative attitudes towards foreigners. Recall that the variable MANY is equal to one when individuals declared that their neighborhood had many foreigners, and zero otherwise. The estimated

\footnotetext{
${ }^{10}$ A series of joint hypothesis tests are performed, though not reported, using the likelihood ratio test in order to find a fault line between distinctive groups which show different attitudes between them in 1988 and 1997. The tests confirm what we describe in the text; the distinction can be found between a group we called labor market competitors and others in 1988 and between students and other categories in 1997.
} 
coefficient on this variable is positive and statistically significant at the 1 percent significance level. Similarly, the variable FEW, which is equal to one when people stated that their neighborhood had a few foreigners, displays a positive coefficient, but it is not statistically significant. In fact, additional analysis indicates that the hypothesis $\beta$ (Many Foreigners $)=\beta$ (Few Foreigners $)$ can be rejected (the likelihood ratio test statistic was 73.437 with one degree of freedom). There is definitely a stronger anti-foreigner sentiment among people whose neighborhoods have many foreigners when compared to those who have few or no foreigners in their neighborhood.

Tables 5 and 6 show the estimated coefficients of the variable DISTURBING, which is equal to one if the person finds people of a different race disturbing and zero otherwise. The estimated coefficient on this variable is positive and statistically significant (at the 1 percent significance level) in both 1988 and 1997. This indicates that racial prejudice is associated with stronger negative sentiments towards foreigners.

Tables 5 and 6 present our results using the variable "too many foreigners in our country" as the dependent variable. Table 7 carries out a probit analysis adopting the dependent variable ANTI-FOREIGNER, which is equal to one if the respondent declares that foreigners are "bad" or "a little bad" for the future of their country, and zero otherwise. This dependent variable is only available in 1988 and it does not allow an analysis of changes in attitudes over time. However, we report our results for 1988 because it represents a dependent variable which more directly reflects anti-foreign sentiment. The results, though, are remarkably consistent with those presented in Table 6 using the alternative measure of anti-foreign attitudes. For instance, the estimated coefficient on the variable LABOR MARKET COMPETITOR is again positive and statistically significant in determining anti-foreigner attitudes. This means that the economic strain felt by people who compete or have competed with foreigners in the labor market strengthen negative attitudes towards 
foreigners. Also, the neighborhood variable, reflecting the existence of "many foreigners" in the neighborhood, is also positively associated to negative attitudes towards foreigners. Finally, the coefficient on the variable DISTURBING, reflecting racial bias, is also positive and statistically significant, showing that those who find the presence of another race disturbing also tend to feel foreigners are bad for the country.

The results of probit models and hypothesis tests imply that people who are -or werecompetitors of immigrants in the labor market (those who are employed at wage/salary jobs, unemployed or retired) have more strongly negative attitudes towards immigrants, when compared with people who do not compete with immigrants in the labor market (students, non-retired people out of the labor force and the self-employed). This is especially so in 1988. This may be because there is a perception-whether correctly or incorrectly--that the economic strain facing them through labor market unemployment and sluggish wages is due to the presence of immigrants in the labor market. We do not find evidence, however, that the unemployed and the employed have different attitudes towards immigrants, a dichotomy emphasized (or perhaps overemphasized) by the previous literature. In 1997, we find that only students differ in their attitude towards immigrants, compared to other groups. Our results also show that people who live in neighborhoods with a greater concentration of foreigners tend to have stronger negative attitudes towards foreigners. The increasing contact with foreigners might ignite racial bias and discrimination against foreigners. Those with racial prejudice are also prejudiced against foreigners.

\section{Changes in Attitudes: A Decomposition Analysis}

In this section, we seek to explain the jump in hostile attitudes towards foreigners in Europe between 1988 and 1997. There are two broad approaches to explaining the changes in attitudes over 
time. One relies on the possibility that the characteristics of individuals that give rise to negative attitudes towards immigrants have changed over time, increasing the dislike of foreigners. For instance, those who feel that they are being hurt by immigrants through their current competition in the labor market (such as the employed, whose wages may decline as a result of immigration, or the unemployed, whose employment opportunities may shrink), as well as those who feel they were hurt by the labor market competition suffered from immigrants in the past (the retired population), can have strong negative feelings towards foreigners. If the number of these labor market competitors of immigrants then rises in the population, one expects that the society will suffer from more negative attitudes towards foreigners. Indeed, in the Eurobarometer surveys, the proportion of the population that competes (or has competed) with immigrants in the labor market increased from 57 percent in 1988 to 66 percent in 1997. More generally, we can describe this type of explanation as a characteristics effect, because it reflects how changes in the characteristics of individuals over time affect the likelihood that someone has negative attitudes towards foreigners.

Suppose, on the other hand, that individual characteristics were not different in 1988 and 1997. A second approach to explaining the rising negative attitudes towards foreigners relies on the possibility that the effects of the given individual characteristics on attitudes have changed over time. For example, suppose that those individuals who are competing -or have competed-- with foreigners in the labor market become more frustrated over time as a result of the lasting economic strain they suffer. This may spillover into stronger negative attitudes towards foreigners. This suggests that the increased bias against foreigners is not due to rising unemployment or a more sluggish economy, but rather to the fact that the unemployment and recession have lasted for so long, causing people to develop more strongly anti-foreigner attitudes. In terms of our earlier analysis, this type of explanation is reflected in the higher coefficients of the variables EMPLOYED, UNEMPLOYED 
and RETIRED in the probit equations explaining negative attitudes towards foreigners. As an example, the probit coefficient on the variable UNEMPLOYED reported in Table 5 rises from 0.257 in 1988 to 0.274 in 1997 , suggesting that the unemployed had more strongly negative attitudes towards foreigners in 1997 than in 1988. More generally, this type of effect is associated with changes in the coefficients of the probit equations between 1988 and 1997, and we may refer to it as a coefficients effect.

Algebraically, the changes between years $A$ and $B$ in the average probability of having antiforeigner attitudes $\left(\bar{P}_{A}-\bar{P}_{B}\right)$, where $A=1997$ and $B=1988$, may be decomposed into two components which represent the characteristics effect and coefficients effect. Asymptotically, this is, ${ }^{11}$

$$
\bar{P}_{A}-\bar{P}_{B}=\left(\overline{\Phi\left(\sum_{i=1}^{i=k} X_{A}^{i} \beta_{B}^{i}\right)}-\overline{\Phi\left(\sum_{i=1}^{i=k} X_{B}^{i} \beta_{B}^{i}\right)}\right)+\left(\overline{\Phi\left(\sum_{i=1}^{i=k} X_{A}^{i} \beta_{A}^{i}\right)}-\overline{\Phi\left(\sum_{i=1}^{i=k} X_{A}^{i} \beta_{B}^{i}\right)}\right)
$$

where $\Phi$ is standard normal cumulative distribution function, $\beta_{A}$, and $\beta_{B}$ are sets of estimated coefficients for each year, and $X_{A}$ and $X_{B}$ include the mean values of the various explanatory variables used in the probit equations.

The above decomposition provides us with the overall coefficient and characteristics effects. In order to find the relative contribution of each variable to changes in negative attitudes towards foreigners between 1988 and 1997, in terms of characteristics and coefficients effects, we employ a decomposition equation for the probit model of the following type [as proposed by Yun (2000)];

\footnotetext{
${ }^{11}$ A decomposition equation with a different parameterization is also possible. The results of the other version of the decomposition equation are available from the authors upon request.
} 


$$
\begin{aligned}
\bar{P}_{A}-\bar{P}_{B} & =\sum_{i=1}^{i=k} W_{\Delta X}^{i}\left(\overline{\Phi\left(\sum_{i=1}^{i=k} X_{A}^{i} \beta_{B}^{i}\right)}-\overline{\Phi\left(\sum_{i=1}^{i=k} X_{B}^{i} \beta_{B}^{i}\right)}\right) \\
& +\sum_{i=1}^{i=k} W_{\Delta \beta}^{i}\left(\overline{\Phi\left(\sum_{i=1}^{i=k} X_{A}^{i} \beta_{A}^{i}\right)}-\overline{\Phi\left(\sum_{i=1}^{i=k} X_{A}^{i} \beta_{B}^{i}\right)}\right),
\end{aligned}
$$

where

$$
W_{\Delta X}^{i}=\frac{\left(\bar{X}_{A}^{i}-\bar{X}_{B}^{i}\right) \beta_{B}^{i} \phi\left(\sum_{i=i}^{i=k} \bar{X}_{B}^{i} \beta_{B}^{i}\right)}{\sum_{i=1}^{i=k}\left(\bar{X}_{A}^{i}-\bar{X}_{B}^{i}\right) \beta_{B}^{i} \phi\left(\sum_{i=i}^{i=k} \bar{X}_{B}^{i} \beta_{B}^{i}\right)} \text { and } W_{\Delta \beta}^{i}=\frac{\bar{X}_{A}^{i}\left(\beta_{A}^{i}-\beta_{B}^{i}\right) \phi\left(\sum_{i=i}^{i=k} \bar{X}_{A}^{i} \beta_{A}^{i}\right)}{\sum_{i=1}^{i=k} \bar{X}_{A}^{i}\left(\beta_{A}^{i}-\beta_{B}^{i}\right) \phi\left(\sum_{i=i}^{i=k} \bar{X}_{A}^{i} \beta_{A}^{i}\right)}
$$

where $\phi$ is a standard normal probability density function. ${ }^{12}$

Table 8 reports the results of this decomposition analysis. The probit equations upon which we base the decompositions were presented at the second and third columns in Table 5 and represent the results of our analysis for 1988 and 1997 (no neighborhood variables). In essence, we decompose the changes in the probability of having negative attitudes towards foreigners between 1988 and 1997, as measured by the variable TOO-MANY-FOREIGNERS in the Eurobarometer surveys. This probability, which is the percentage of the sample who believed that there were "too many" foreigners in their country, rises sharply from 29.5 percent to 42.1 percent between 1988 and 1997.

The bottom row in Table 8 (symbolized by SUM) shows the overall effects of characteristics versus coefficients in explaining the increased negative attitudes towards foreigners, while the terms above depict the role of various variables. About 12 percent of the increased anti-foreigner attitudes are explained by differences in people's characteristics between the two years. This means that if

\footnotetext{
${ }^{12}$ Because of non-linearity of the standard normal cumulative distribution function, two types of approximation have been used to find the weights $\left(W_{\Delta X}^{i}, W_{\Delta \beta}^{i}\right)$; approximation the value of average of the standard normal distribution function, $\overline{\Phi\left(\sum_{i=1}^{i=k} X^{i} \beta^{i}\right)}$, with that of standard normal distribution evaluated at average value of exogenous variables, $\Phi\left(\sum_{i=1}^{i=k} \overline{X^{i}} \beta^{i}\right)$, and Taylor expansion of $\Phi\left(\sum_{i=1}^{i=k} \overline{X_{A}^{i}} \beta_{B}^{i}\right)$ about $\overline{X_{A}^{i}} \beta_{B}^{i}=\overline{X_{A}^{i}} \beta_{A}^{i}$ or $\overline{X_{A}^{i}} \beta_{B}^{i}=\overline{X_{B}^{i}} \beta_{B}^{i}$ is used [for details, see Yun(2000)].
} 
people in the sample have had the same characteristics in 1988 and 1997, then the increased probability of having anti-foreigner sentiment would have been 12 percent less. The variable with the largest effect among the various individual characteristics affecting attitudes is DISTURBING, which rises sharply between 1988 and 1997. This means that rising prejudice accounts for 12 percent of the rise in anti-foreigner attitudes. The increased proportion of the employed, the unemployed and the retired in the population also explain some of the rising negative attitudes towards foreigners, but this is less than 6 percent. On the other hand, the increased educational attainment of the population acted to lower the anti-foreigner sentiment between 1988 and 1997.

The majority ( 88 percent) of the increased anti-foreigner sentiment is explained by the differences in probit coefficients between 1988 and 1997. One could refer to these as behavioral changes since they represent the changes in the strength of the various individual characteristics influencing attitudes towards foreigners. ${ }^{13}$ If in both years the various variables influencing attitudes towards foreigners had the same strength (their coefficients in the probit equation had been equal), then about 88 percent of the increased probability of having negative attitudes towards foreigners would disappear.

First, among the various coefficient effects, it is remarkable that the coefficient of educational attainment became less negative between 1988 and 1997. This means that the strength of the ameliorating impact of education on anti-foreigner attitudes diminished over time. This explains about 40 percent of the increased anti-foreigner attitudes between 1988 and 1997. In other words, the educated are increasingly displaying anti-foreigner attitudes in Europe and this accounts for a

${ }^{13}$ In the well-known Blinder-Oaxaca decomposition analysis for wage differentials, the part explained by the differences in coefficients is usually called "discrimination." In the decomposition analysis utilized in this paper, "behavioral differences" or "behavioral changes" are a better descriptor. 
substantial portion of the overall increased anti-foreigner attitudes in the European Union. Second, the coefficient on the DISTURBING variable rises between 1988 and 1997, meaning that racial bias appears to be reflected in anti-foreigner behavior more strongly in 1997 than in 1988. This explains about 8 percent of the rising probability of negative attitudes towards foreigners. Third, the strength of being (or having been) a labor market competitor of immigrants increases the negative attitudes towards immigrants over time. Employed (salaried) workers, for example, displayed a significantly higher hostility towards foreigners, increasing the probability of anti-foreigner sentiment by 15 percent between 1988 and 1997. However, the self-employed and the non-retirees who are out of the labor force also contribute to increasing negative attitudes between the two years. This obviously results from the fact that the coefficients of the two categories are significantly positive in 1997 while they are not significant in 1988, as discussed in the previous section.

There are other interesting findings. The coefficient effect of age structure (age and age squared taken together) is negative, implying that the negative attitudes of older people, in general, towards immigrants declined in strength between 1988 and 1997. This helped to reduce antiimmigrant sentiments, but clearly not enough to compensate for the other coefficients -or behavioral-- changes over time. The changes in the constant term also contribute significantly to increasing negative attitudes towards foreigners. The constant term may reflect underlying changes in attitudes towards foreigners between 1988 and 1997 which are not captured by the other explanatory variables.

\section{Summary and Conclusions}

This paper has examined the relative significance of some of the key forces that influence the attitudes of European Union citizens towards foreigners (non-European Union people). Using 
attitudinal survey data from the 1988 and 1997 Eurobarometer surveys, we analyze the role of labor market competition, immigrant concentration, racial/ethnic bias, educational attainment, and a set of other variables that potentially determine attitudes towards immigrants. Estimating probit equations of the likelihood that people in the sample had negative attitudes towards foreigners, the paper provides an analysis of the connections between an array of explanatory variables and negative attitudes towards (non-European Union) foreigners.

The Eurobarometer survey finds a sharp increase in anti-foreigner attitudes in Europe between 1988 and 1997. For instance, in 1988, a total of 29.5 percent of the sample felt that there were "too many foreigners" in their country, but by 1997 this percentage had risen to 42.1 percent. What are the factors that explain negative attitudes towards foreigners? We find that people who directly compete (or have competed) in the labor market with immigrants have stronger negative attitudes towards foreigners, ceteris paribus. This includes not only the unemployed but also employed, salaried workers (who may perceive that their wages are negatively affected by immigrants), and the retired (who may have developed anti-foreigner attitudes in the past, when they were employees in the labor market). This is especially true in 1988. By 1997 students stand out as the one group with minimal anti-foreigner attitudes.

We also find strong evidence that a greater concentration of foreigners in the neighborhoods where citizens reside also raises the probability of a person displaying negative attitudes towards foreigners, holding other things constant. This may suggest that ethnic bias and discrimination are key forces generating negative attitudes towards foreigners. Larger concentrations of immigrants, being more visible, can set afire the ethnocentric sentiments of prejudiced individuals. Communities with larger concentrations of immigrants may give rise to greater anti-immigrant sentiment. The significance of racial/ethnic prejudice is confirmed by our finding that people who "feel disturbed 
by people of a different race" also have stronger negative attitudes towards foreigners, holding other things constant.

Educational attainment is found to be a strong antidote to anti-foreigner sentiments. Older people, on the other hand, generally have stronger negative attitudes towards foreigners. And, contrary to our expectations, people who have children less than 15 years of age tend to have more positive attitudes towards foreigners, holding other things constant. This may be explained by the increased likelihood that the children of natives will mix with the children of immigrants, increasing the contact and diffusing the tensions between the adults in the two groups.

Using our probit decomposition analysis of the factors determining negative attitudes towards foreigners, we were also able to provide some explanations for the jump in hostile attitudes towards foreigners in Europe between 1988 and 1997. There are two broad approaches to explaining the changes in attitudes over time. One relies on the possibility that the characteristics of individuals that give rise to negative attitudes towards immigrants have changed over time, incrementing the dislike of foreigners. We describe this type of explanation as a characteristics effect. A second approach relies on the possibility that the effects of the given individual characteristics on attitudes have changed over time. This type of effect is associated with changes in the coefficients of the probit equations between 1988 and 1997, and we may refer to it as a coefficients effect.

The decomposition analysis indicates that about 12 percent of the increased anti-foreigner attitudes displayed by the people sampled in the Eurobarometer survey are explained by differences in people's characteristics between the two years. The variable with the largest effect among the various individual characteristics affecting attitudes is racial prejudice. The increased proportion of people who compete-or have competed-- with immigrants in the labor market explains some of the rising negative attitudes towards foreigners, but only less than 6 percent. On the other hand, the 
increased educational attainment of the population acted to lower the anti-foreigner sentiment between 1988 and 1997.

We also find that 88 percent of the rising anti-foreigner sentiment is explained by coefficient effects. This means that most of the increased anti-foreigner sentiment is related to behavioral changes among the population that has strengthened the impact of various individual characteristics on negative attitudes towards foreigners. Key among these behavioral changes is the fact that the strength of the ameliorating impact of education on anti-foreigner attitudes diminished over time. In other words, the highly-skilled are increasingly displaying anti-foreigner attitudes in Europe and this accounts for close to 42 percent of the overall increased anti-foreigner attitudes in the Union. In addition, racial bias appears to be reflected in stronger anti-foreigner behavior in 1997 than in 1988. On the other hand, the negative attitudes of older people in general towards immigrants declined in strength between 1988 and 1997. This helped to reduce anti-immigrant sentiments, but clearly not enough to compensate for the other behavioral changes over time. Finally, the strength of being (or having been) a labor market competitor of immigrants increases negative attitudes towards immigrants over time. Employed (salaried) workers, for example, displayed a significantly greater hostility towards foreigners, increasing the probability of anti-foreigner sentiment by close to 15 percent between 1988 and 1997. Moreover, the self-employed and non-retirees out of the labor force together increased their hostility towards immigrants by 18 percent between 1988 and 1997.

The rising anti-foreigner trend documented by the Eurobarometer surveys is alarming and requires serious discussion and policy responses. Particularly sobering is the finding that increased educational attainment, one of the most significant variables acting to reduce anti-foreigner sentiment, diminished its role between 1988 and 1997, with a growing number of skilled workers 
displaying anti-foreigner sentiment. Our analysis strongly suggests that European countries face a major challenge in battling the ignorance and the social environment that give rise to prejudice and discrimination. 


\section{REFERENCES}

Alber, Jens, "Toward Explaining Anti-Foreigner Violence in Germany," Working Paper No. 53, Center for European Studies, Harvard University, 1994.

Amemiya, Takeshi, Advanced Econometrics, Cambridge: Harvard University Press, 1985.

Bauer, Tomas K., Magnus Lofstrom, and Klaus F. Zimmermann, "Immigration Policy, Assimilation of Immigrants and Natives' Sentiments toward Immigrants: Evidence from 12 OECD-Countries," Swedish Economic Policy Review, 7, 2000, 11-53.

Card, David, "Immigrant Inflows, Native Outflows, and the Local Labor Market Impacts of Higher Immigration," Journal of Labor Economics, 19, 2001, 22-64.

Card, David, "The Impact of the Mariel Boatlift on the Miami Labor Market," Industrial and Labor Relations Review, 43, 1990, 245-257.

Channel 4 Hate Commission, Hate Crime Report, London, 2000.

DeNew, John P. and Klaus F. Zimmermann, "Native Wage Impacts of Foreign Labor: A Random Effects Panel Analysis," Journal of Population Economics, 7, 1994, 177-192.

Dustmann, Christian and Ian Preston, "Attitudes to Ethnic Minorities, Ethnic Context and Location Decisions,"Economic Journal, 111, 2001, 353-373.

Dustmann, Christian and Ian Preston, "Racial and Economic Factors in Attitudes to Immigration," IZA discussion paper, No. 190, 2000.

European Monitoring Centre on Racism and Xenophobia (EUMC) Annual Report 1999, European Commission, Brussels, 2000.

Fertig, Michael and Christoph M. Schmidt, "First- and Second-Generation Immigrants: What Do We Know and What Do People Think," forthcoming in: Rotte, Ralph (ed.), Migration Policy and the Economy: International Experiences, 2001.

Gang, Ira N. and Francisco L. Rivera-Batiz, "Labor Market Effects of Immigration in the United States and Europe: Substitution vs. Complementarity," Journal of Population Economics, 7, 1994, 157-75. (a)

Gang, Ira N. and Francisco L. Rivera-Batiz, "Unemployment and Attitudes Toward Foreigners in Germany," in G. Steinmann and R. Urich, eds., Economic Consequences of Immigration in Germany, Germany: Physica-Verlag, 1994, 121-154. (b)

Gutierrez, David G., Walls and Mirrors: Mexican Americans, Mexican Immigrants and the 
Politics of Ethnicity, University of California Press, Berkeley, 1995.

Hunt, Jennifer, "The Impact of the 1962 Repatriates from Algeria on the French Labor market," Industrial and Labor relations Review, 45, 1992, 556-72.

Krueger, Alan B. and Jorn-Steffen Pischke, "A Statistical Analysis of Crime Against Foreigners in Unified Germany," Journal of Human Resources, 32, 1997, 182-209.

Lyall, Sarah, "In Ravaged English City, Racial Mix was Volatile,” The New York Times, May 31, 2001, p. A4.

Massey, Douglas S. and Nancy A. Denton, American Apartheid: Segregation and the Making of the Underclass, Harvard University Press, Cambridge, 1993.

Melich, Anna. Eurobarometer 48: Holiday Travel, October-November 1997 [Computer file]. Ann Arbor, MI: Inter-university Consortium for Political and Social Research [distributors], 1999.

Muhleisen, Martin and Klaus F. Zimmermann, "A Panel Analysis of Job Changes and Unemployment," European Economic Review, 38, 1994, 793-801.

OECD, Trends in International Migration (SOPEMI), Paris, 1998, 2001.

Reif, Karlheinz, and Anna Melich. Euro-Barometer 30: Immigrants and Out-Groups in Western Europe, October-November 1988 File, Ann Arbor MI: Inter-University Consortium for Political and Social Research Producer and Distributor, 1991.

Winkelmann, Rainer and Klaus F. Zimmermann, "Ageing, Migration and Labor Mobility," in Paul Johnson and Klaus F. Zimmermann, eds., Labor Markets in an Aging Europe. Cambridge: Cambridge University Press, 1993, 255-282.

Winter-Ebmer, Rudolf and Josef Zweimueller, "Do Immigrants Displace Native Workers?," manuscript, University of Linz, Austria, 1994.

Yun, Myeong-Su, "Decomposition Analysis for a Binary Choice Model," Working Paper, No. 2000-01, Department of Economics, Rutgers University, 2000.

Yuengert, Andrew M., "Testing Hypotheses of Immigrant Self-Employment,” Journal of Human Resources, 30, 1995, 194-204.

Zimmermann, Klaus F., "Tackling the European Migration Problem," Journal of Economic Perspectives, 9, 1995, 45-62. 


\section{Table 1. The Fraction of Foreigners in the Population} (\% of the population, by country)

Country

Austria

Belgium

Denmark

Finland

France

Germany

Ireland

Italy

Luxembourg

Netherlands

Portugal

Spain

Sweden

United Kingdom

Note: * Data is for 1990.

Source: OECD (1998, 2001).
1985

1998

4.0

9.1

8.6

8.7

2.3

4.8

0.3

1.6

$-$

7.2

$6.4^{*}$

2.3

0.7

26.7

3.8

1.0

0.6

$4.6 \quad 5.6$

$\begin{array}{ll}3.1 & 3.8\end{array}$
35.6

4.2

1.8

1.8

$4.6 \quad 5.6$

$\begin{array}{ll}3.1 & 3.8\end{array}$

8.9

3.0

2.1

2

8 


\section{Table 2. Stocks of Foreign Population in Selected European Countries,} by Nationality, 1998

\begin{tabular}{|c|c|c|c|c|c|c|}
\hline \multirow{3}{*}{$\begin{array}{l}\text { Total Foreigner } \\
\text { Population } \\
\text { (Thousands) }\end{array}$} & \multicolumn{6}{|c|}{ Recipient Country } \\
\hline & Belgium & France $* * *$ & Germany & Italy & Netherlands & U.K. $* * * *$ \\
\hline & 892 & 3,607 & 7,320 & 1,250 & 662 & 2,208 \\
\hline $\begin{array}{l}\text { Foreigners Fron } \\
\text { EEC Countries }\end{array}$ & $63 \%$ & $36 \%$ & $25 \%$ & $14 \%$ & $29 \%$ & $40 \%$ \\
\hline Italy & $23 \%$ & $7 \%$ & $8 \%$ & & $3 \%$ & $4 \%$ \\
\hline Spain & $5 \%$ & $6 \%$ & $2 \%$ & & $3 \%$ & $2 \%$ \\
\hline Portugal & $3 \%$ & $18 \%$ & $2 \%$ & & $1 \%$ & $2 \%$ \\
\hline Greece & $2 \%$ & & $5 \%$ & & $1 \%$ & \\
\hline France & $12 \%$ & & $1 \%$ & $2 \%$ & & $3 \%$ \\
\hline Netherlands & $9 \%$ & & $2 \%$ & & & \\
\hline Germany & $4 \%$ & & & $3 \%$ & $8 \%$ & $4 \%$ \\
\hline U.K.* & $3 \%$ & & $2 \%$ & $2 \%$ & $6 \%$ & \\
\hline Belgium & & & & & $4 \%$ & \\
\hline Ireland & & & & & & $20 \%$ \\
\hline $\begin{array}{l}\text { Foreigners Fron } \\
\text { Non-EEC } \\
\text { Countries }\end{array}$ & $37 \%$ & $64 \%$ & $75 \%$ & $86 \%$ & $71 \%$ & $60 \%$ \\
\hline Morocco & $14 \%$ & $16 \%$ & & $12 \%$ & $19 \%$ & \\
\hline Algeria & $1 \%$ & $17 \%$ & & & & \\
\hline Turkey & $8 \%$ & $6 \%$ & $29 \%$ & & $15 \%$ & \\
\hline Tunisia & $1 \%$ & $6 \%$ & & $4 \%$ & & \\
\hline Poland & $1 \%$ & $1 \%$ & $4 \%$ & $2 \%$ & & \\
\hline Yugoslavia & $1 \%$ & $1 \%$ & $15 \%$ & $3 \%$ & $3 \%$ & \\
\hline USA & $1 \%$ & & $1 \%$ & $4 \%$ & $2 \%$ & $6 \%$ \\
\hline $\begin{array}{l}\text { Caribbean/ } \\
\text { Guyana }\end{array}$ & & & & & & $3 \%$ \\
\hline Asia & $3 \%$ & & & $11 \%$ & & $14 \%$ \\
\hline SS Africa** & $1 \%$ & $1 \%$ & & $3 \%$ & & $6 \%$ \\
\hline
\end{tabular}

Note: Individual country data are presented only for those foreign groups with the largest populations in the host country.

* Includes Hong Kong.

**Selected Sub-Saharan African countries in France and Italy (Senegal) and Belgium(Congo).

$* * * 1990$.

$* * * * 1999$.

Source: OECD (2001). 
Table 3. Attitudes of European Residents towards Foreigners

\begin{tabular}{|c|c|c|c|c|c|}
\hline & \multicolumn{3}{|c|}{1988} & \multicolumn{2}{|c|}{1997} \\
\hline & $\begin{array}{l}\text { Anti- } \\
\text { Foreigners }\end{array}$ & $\begin{array}{l}\text { Too Many } \\
\text { Foreigners }\end{array}$ & $\begin{array}{l}\text { Sample } \\
\text { Size }\end{array}$ & $\begin{array}{l}\text { Too Many } \\
\text { Foreigners }\end{array}$ & $\begin{array}{l}\text { Sample } \\
\text { Size }\end{array}$ \\
\hline Overall & $31.40 \%$ & $29.50 \%$ & 9,775 & $42.10 \%$ & 11,868 \\
\hline $\begin{array}{l}\text { Employed-Wage/Salary } \\
\text { Jobs }\end{array}$ & $31.84 \%$ & $29.86 \%$ & 3,794 & $40.36 \%$ & 5,154 \\
\hline Unemployed & $31.37 \%$ & $33.50 \%$ & 612 & $42.30 \%$ & 896 \\
\hline Retired & $38.05 \%$ & $39.13 \%$ & 1,201 & $52.25 \%$ & 1,776 \\
\hline Self-Employed & $32.29 \%$ & $27.69 \%$ & 1,087 & $44.48 \%$ & 1,223 \\
\hline Students & $26.15 \%$ & $19.82 \%$ & 1,105 & $26.71 \%$ & 1,243 \\
\hline $\begin{array}{l}\text { Non-retirees out of the } \\
\text { labor force }\end{array}$ & $28.95 \%$ & $28.14 \%$ & 1,976 & $46.51 \%$ & 1,576 \\
\hline $\begin{array}{l}\text { Many Foreigners in the } \\
\text { neighborhood }\end{array}$ & $41.98 \%$ & $46.20 \%$ & 892 & & \\
\hline $\begin{array}{l}\text { Few Foreigners in the } \\
\text { neighborhood }\end{array}$ & $31.48 \%$ & $28.13 \%$ & 4,209 & & \\
\hline $\begin{array}{l}\text { No Foreigners in the } \\
\text { neighborhood }\end{array}$ & $29.47 \%$ & $27.80 \%$ & 4,737 & & \\
\hline $\begin{array}{l}\text { Disturbed by the existence } \\
\text { of other race }\end{array}$ & $65.24 \%$ & $63.18 \%$ & 1,165 & $79.85 \%$ & 1,841 \\
\hline $\begin{array}{l}\text { Not disturbed by the } \\
\text { existence of other race }\end{array}$ & $26.82 \%$ & $24.95 \%$ & 8,610 & $35.17 \%$ & 10,027 \\
\hline
\end{tabular}

Note: ANTI-FOREIGNERS has a value of one when the respondent says that the presence of foreigners are bad for the future of the country. TOO-MANY-FOREIGNERS has a value of one when the respondent feels that there are too many foreigners in the country.

Source: Eurobarometer survey, 1988, 1997; authors' calculations. 
Table 4. Sample Means

\begin{tabular}{|c|c|c|c|c|}
\hline \multirow{2}{*}{$\begin{array}{l}\text { Variable } \\
\text { Age }\end{array}$} & \multicolumn{2}{|c|}{1988} & \multicolumn{2}{|c|}{1997} \\
\hline & 40.01 & $(15.67)$ & 40.85 & $(15.32)$ \\
\hline Years of Education & 11.23 & $(3.04)$ & 11.81 & $(4.39)$ \\
\hline Children 15 (No. of Children less than 15) & 0.65 & $(1.02)$ & 0.59 & $(0.95)$ \\
\hline Head of Household & 0.49 & $(0.50)$ & 0.53 & $(0.50)$ \\
\hline Male & 0.49 & $(0.50)$ & 0.49 & $(0.50)$ \\
\hline \multicolumn{5}{|l|}{ Labor Force Status } \\
\hline Employed: Wage/Salary Jobs & 0.39 & $(0.49)$ & 0.43 & $(0.50)$ \\
\hline Unemployed & 0.06 & $(0.24)$ & 0.08 & $(0.26)$ \\
\hline Retired & 0.12 & $(0.33)$ & 0.15 & $(0.36)$ \\
\hline Self-Employed & 0.11 & $(0.31)$ & 0.10 & $(0.30)$ \\
\hline Students & 0.11 & $(0.32)$ & 0.10 & $(0.31)$ \\
\hline Non-retirees out of the labor force & 0.20 & $(0.40)$ & 0.13 & $(0.34)$ \\
\hline Disturbing (Disturbed by the Existence of Other Race) & 0.12 & $(0.32)$ & 0.16 & $(0.36)$ \\
\hline \multicolumn{5}{|l|}{ Foreigners in the Neighborhood } \\
\hline Many Foreigners & 0.08 & $(0.28)$ & & \\
\hline Few Foreigners & 0.43 & $(0.50)$ & & \\
\hline No Foreigners & 0.48 & $(0.50)$ & & \\
\hline $\begin{array}{l}\text { Too Many Foreigners (Feel that There are Too Many } \\
\text { Foreigners in their Country) }\end{array}$ & 0.30 & $(0.46)$ & 0.42 & $(0.49)$ \\
\hline $\begin{array}{l}\text { Anti-Foreigners (the Presence of Foreigners is "Bad" or } \\
\text { a "Little Bad" for the Future of the Country) }\end{array}$ & 0.31 & $(0.46)$ & & \\
\hline Number of Observations & \multicolumn{2}{|c|}{9,775} & \multicolumn{2}{|c|}{11,868} \\
\hline
\end{tabular}

Note: Standard deviations are reported in parentheses.

Source: Eurobarometer Survey, 1988, 1997; authors' calculations. 
Table 5. Probit Analysis of Attitudes Towards Foreigners

\section{Dependent variable: Too Many Foreigners}

\begin{tabular}{|c|c|c|c|c|c|c|}
\hline \multirow[b]{3}{*}{ Variable } & \multicolumn{2}{|c|}{1988} & \multicolumn{2}{|c|}{1988} & \multicolumn{2}{|c|}{1997} \\
\hline & \multicolumn{2}{|c|}{$\begin{array}{l}\text { With Neighborhood } \\
\text { Variables }\end{array}$} & \multicolumn{2}{|c|}{$\begin{array}{l}\text { No Neighborhood } \\
\text { Variables }\end{array}$} & \multicolumn{2}{|c|}{$\begin{array}{l}\text { No Neighborhood } \\
\text { Variables }\end{array}$} \\
\hline & Estimate & (S. E.) & Estimate & (S. E.) & Estimate & (S. E.) \\
\hline Constant & $-0.650 * *$ & $(0.130)$ & $-0.622 * *$ & $(0.130)$ & $-0.410 * *$ & $(0.105)$ \\
\hline Age & 0.012 & $(0.007)$ & 0.012 & $(0.007)$ & 0.001 & $(0.006)$ \\
\hline Age Square / 100 & -0.011 & $(0.008)$ & -0.010 & $(0.008)$ & 0.003 & $(0.007)$ \\
\hline Years of Education & $-0.039 * *$ & $(0.005)$ & $-0.035 * *$ & $(0.005)$ & $-0.022 * *$ & $(0.003)$ \\
\hline Children 15 & $-0.059 * *$ & $(0.015)$ & $-0.064 * *$ & $(0.015)$ & $-0.050 * *$ & $(0.014)$ \\
\hline Head of Household & -0.013 & $(0.038)$ & 0.003 & $(0.038)$ & -0.034 & $(0.030)$ \\
\hline Male & -0.000 & $(0.036)$ & -0.015 & $(0.036)$ & $-0.070 *$ & $(0.028)$ \\
\hline Self-Employed & 0.039 & $(0.073)$ & 0.025 & $(0.073)$ & $0.337 * *$ & $(0.066)$ \\
\hline Employed & $0.160 * *$ & $(0.060)$ & $0.155^{*}$ & $(0.060)$ & $0.283 * *$ & $(0.054)$ \\
\hline Unemployed & $0.253 * *$ & $(0.076)$ & $0.257 * *$ & $(0.075)$ & $0.274 * *$ & $(0.066)$ \\
\hline Retired & $0.244 * *$ & $(0.080)$ & $0.230 * *$ & $(0.080)$ & $0.371 * *$ & $(0.069)$ \\
\hline $\begin{array}{l}\text { Non-retirees out of } \\
\text { the labor force }\end{array}$ & 0.041 & $(0.073)$ & 0.029 & $(0.072)$ & $0.301 * *$ & $(0.065)$ \\
\hline Disturbing & $0.960 * *$ & $(0.041)$ & $0.990 * *$ & $(0.041)$ & $1.183 * *$ & $(0.036)$ \\
\hline Many Foreigners & $0.445 * *$ & $(0.051)$ & & & & \\
\hline Few Foreigners & 0.011 & $(0.030)$ & & & & \\
\hline Log-Likelihood & -54 & 9.998 & & 1.064 & -72 & 4.283 \\
\hline
\end{tabular}

Note: Dependent variable is a binary variable, Too Many Foreigners, and ** and * mean statistically significant at $1 \%$ and $5 \%$ levels, respectively. The reference group of occupation is Student.

Source: Eurobarometer Survey, 1988, 1997; authors' calculations. 
Table 6. Probit Analysis of Attitudes Towards Foreigners

\section{Dependent variable: Too Many Foreigners}

\begin{tabular}{|c|c|c|c|c|c|c|}
\hline \multirow[b]{3}{*}{ Variable } & \multicolumn{2}{|c|}{1988} & \multicolumn{2}{|c|}{1988} & \multicolumn{2}{|c|}{1997} \\
\hline & \multicolumn{2}{|c|}{$\begin{array}{l}\text { With Neighborhood } \\
\text { Variables }\end{array}$} & \multicolumn{2}{|c|}{$\begin{array}{l}\text { No Neighborhood } \\
\text { Variables }\end{array}$} & \multicolumn{2}{|c|}{$\begin{array}{l}\text { No Neighborhood } \\
\text { Variables }\end{array}$} \\
\hline & Estimate & (S. E.) & Estimate & (S. E.) & Estimate & (S. E.) \\
\hline Constant & $-0.591 * *$ & $(0.126)$ & $-0.567 * *$ & $(0.125)$ & $-0.449 * *$ & $(0.100)$ \\
\hline Age & 0.010 & $(0.006)$ & 0.009 & $(0.006)$ & $0.014^{* *}$ & $(0.005)$ \\
\hline Age Square / 100 & -0.008 & $(0.007)$ & -0.007 & $(0.007)$ & -0.008 & $(0.006)$ \\
\hline Years of Education & $-0.040 * *$ & $(0.005)$ & $-0.036 * *$ & $(0.005)$ & $-0.025^{* *}$ & $(0.003)$ \\
\hline Children 15 & $-0.057 * *$ & $(0.015)$ & $-0.062 * *$ & $(0.015)$ & $-0.043 * *$ & $(0.014)$ \\
\hline Head of Household & -0.012 & $(0.037)$ & 0.002 & $(0.037)$ & -0.024 & $(0.030)$ \\
\hline Male & -0.004 & $(0.034)$ & -0.018 & $(0.034)$ & $-0.077 * *$ & $(0.028)$ \\
\hline $\begin{array}{l}\text { Labor Market } \\
\text { Competitors }\end{array}$ & $0.157 * *$ & $(0.030)$ & $0.161 * *$ & $(0.030)$ & $0.054 *$ & $(0.027)$ \\
\hline Disturbing & $0.961^{* *}$ & $(0.041)$ & $0.992 * *$ & $(0.041)$ & $1.185^{* *}$ & $(0.036)$ \\
\hline Many Foreigners & $0.444^{* *}$ & $(0.051)$ & & & & \\
\hline Few Foreigners & 0.009 & $(0.029)$ & & & & \\
\hline Log-Likelihood & & 2.095 & -55 & 3.149 & & 9.620 \\
\hline
\end{tabular}

Note: Dependent variable is a binary variable, Too Many Foreigners, and $* *$ and $*$ mean statistically significant at $1 \%$ and $5 \%$ levels, respectively. The variable "attached to the formal labor force" has a value of one if employed in wage/salary jobs or unemployed or retired.

Source: Eurobarometer Survey, 1988, 1997; authors' calculations. 


\section{Table 7. Probit Analysis of Anti-Foreign Attitudes}

\section{Dependent variable: Anti-Foreigners}

\begin{tabular}{llclc} 
& \multicolumn{2}{c}{1988} & \multicolumn{2}{c}{1988} \\
Variable & With Neighborhood Variables & Without Neighborhood Variables \\
Constant & Estimate & $($ S. E. $)$ & Estimate & (S. E. $)$ \\
Age & $-0.855^{* *}$ & $(0.122)$ & $-0.839^{* *}$ & $(0.122)$ \\
Age Square / 100 & 0.009 & $(0.006)$ & 0.008 & $(0.006)$ \\
Years of Education & -0.006 & $(0.007)$ & -0.006 & $(0.007)$ \\
Children15 & -0.004 & $(0.005)$ & -0.002 & $(0.005)$ \\
Head of Household & $-0.041^{* *}$ & $(0.015)$ & $-0.044^{* *}$ & $(0.015)$ \\
Male & 0.005 & $(0.036)$ & 0.013 & $(0.036)$ \\
Labor Market & 0.007 & $(0.033)$ & -0.000 & $(0.033)$ \\
Competitors & $0.071^{*}$ & $(0.030)$ & $0.074 *$ & $(0.030)$ \\
Disturbing & & & & \\
Many Foreigners & $0.220^{* *}$ & $(0.050)$ & $0.996^{* *}$ & $(0.041)$ \\
Few Foreigners & 0.029 & $(0.029)$ & & \\
Log-Likelihood & & & & -5737.157
\end{tabular}

Note: Dependent variable is a binary variable, Anti-Foreigners, and ** and * mean statistically significant at 1\% and 5\% levels, respectively. The variable "attached to the formal labor force" has a value of one if employed in wage/salary jobs or unemployed or retired.

Source: Eurobarometer Survey, 1988, 1997; authors' calculations. 


\section{Table 8. Decomposition Analysis of Increase in Anti-Foreigner Attitudes}

\begin{tabular}{lllll} 
& \multicolumn{2}{c}{ Characteristics Effect } & \multicolumn{2}{c}{ Coefficients Effect } \\
Variable & Estimate & Share (\%) & Estimate & Share (\%) \\
Constant & & & 0.0709 & 56.47 \\
Age & 0.0039 & 3.10 & -0.1405 & -111.87 \\
Age Square / 100 & -0.0024 & -1.90 & 0.0834 & 66.36 \\
Years of Education & -0.0083 & -6.61 & 0.0506 & 40.26 \\
Children15 & 0.0017 & 1.36 & 0.0027 & 2.17 \\
Head of Household & 0.0000 & 0.04 & -0.0067 & -5.30 \\
Male & 0.0000 & 0.01 & -0.0090 & -7.19 \\
Employed & 0.0029 & 2.30 & 0.0187 & 14.86 \\
Unemployed & 0.0013 & 1.06 & 0.0005 & 0.36 \\
Retired & 0.0025 & 1.98 & 0.0071 & 5.66 \\
Self-Employed & -0.0001 & -0.07 & 0.0108 & 8.59 \\
Non-retirees out of the & -0.0008 & -0.65 & 0.0121 & 9.62 \\
labor force & & & & \\
Disturbing & 0.0143 & 11.41 & 0.0100 & 7.98 \\
\hline SUM & 0.0151 & 12.04 & 0.1105 & 87.96
\end{tabular}

Note: Percentage share of differences in probabilities of anti-foreigner attitude measured by the variable "Too many" between 1997 and 1988 (0.4210 - 0.2950) are reported.

Source: Eurobarometer Survey, 1988, 1997; authors' calculations. 